\title{
Influences of climacteric in female sexual activity
}

\author{
Influências do climatério na atividade sexual feminina
}

Anthonio Alisancharles Batista de Almeida ${ }^{1}$, Cecília Danielle Bezerra Oliveira ${ }^{1}$, Fabiana Ferraz Queiroga Freitas ${ }^{1}$, Karolliny Abrantes de Sousa ${ }^{1}$, Maria Tibéria da Silva Carolino ${ }^{1}$, Rosimery Cruz de Oliveira Dantas ${ }^{1}$

Objective: to identify complaints of sexual function related to climacteric symptoms among women in climacteric age. Methods: this is an descritive study. A sample of 330 women aged from 35 to 65 years old, with three previous Pap tests. We used a semi-structured questionnaire developed by the researchers. A descriptive statistical analysis was performed having the central tendency of proportion and measure the average as a parameter. Results: it was evidenced that $50.0 \%$ were between $35-45$ years, $73.0 \%$ were sexually active, $59.4 \%$ had decreased libido, and 58.5\% reported dyspareunia. Conclusion: it is necessary that the health services and professionals are aware of the influence of climacteric on women's health to develop strategies aimed at quality of life.

Descriptors: Sexual Behavior; Quality of Life; Climacteric.

Objetivo: identificar queixas da função sexual relacionadas aos sintomas climatério entre mulheres na idade climatérica. Métodos: estudo descritivo. Amostra de 330 mulheres na faixa etária de 35 a 65 anos com três exames de Papanicolau prévios. Utilizou-se questionário semiestruturado elaborado pelos pesquisadores. Realizada análise estatística descritiva, tendo como parâmetro a proporção e medida de tendência central a média. Resultados: evidenciou-se que 50,0\% estavam entre 35-45 anos, 73,0\% tinham vida sexual ativa, 59,4\% apresentavam redução da libido e 58,5\% relataram dispareunia. Conclusão: é necessário que os serviços de saúde e os profissionais estejam conscientes da influência do climatério na saúde da mulher para desenvolver estratégias de atenção visando à qualidade de vida.

Descritores: Comportamento Sexual; Qualidade de Vida; Climatério.

${ }^{1}$ Universidade Federal de Campina Grande, Cajazeiras, PB, Brazil.

Corresponding author: Anthonio Alisancharles Batista de Almeida

Rua Francisco Duarte Sobrinho, 58, - José Alexandre Filho. Poço de José de Moura, CEP: 58908-000. Paraíba, PB, Brazil. E-mail: a.charlesdealmeida@hotmail.com 


\section{Introduction}

Theclimactericis an endocrineand physiological phenomenon resulting from the depletion of ovarian follicles that occurs in all women. It starts around the age of 35 years, extending to 65 years and culminates with menopause ${ }^{(1)}$. It is estimated that about $50.0 \%$ to $70.0 \%$ of women during this physiological process, present as common symptoms hot flashes, sleep disturbances, poor vaginal dryness, loss of libido and stress. These clinical manifestations do not yet have a completely outlined physiological mechanism, but it is known that the decline in estradiol levels is the most important factor for its appearance ${ }^{(2)}$.

It is known that the hormone declines that occur with advancing female age, gradually cause the appearance of anatomical and functional changes, especially in the genitals (hypotrophy or atrophy), leading to the emergence of changes in sexual life, such as: decreased libido, of the frequency and orgasmic response, interfering in the personal sexual satisfaction, but also on their partner ${ }^{(1,3)}$.

Disorders with this etiology are becoming increasingly common since from the beginning of the 80's the life expectancy of the population has considerably grown, causing the woman, commonly, to experience more years after climacteric. This fact causes a need to conduct studies on the subject so that we can develop support strategies that provide a better quality of life for women at this stage, as inevitably with the hormone declines, and they end up becoming more vulnerable to the installation of various morbidities.

Thus, this study aims to identify complaints of sexual function that are related to the climacteric symptoms in women.

\section{Methods}

This is an descritive study performed in all the Family Health Units of Urban Zone in the city of Cajazeiras, Paraíba, Brazil, with coverage area women of each corresponding team and that are attended in that unit.

The study population consisted of all women at climacteric age, registered in the Family Health Units and the sample consisted of 330 women who have performed Pap test, calculated with the formula of a finite population with a Confidence Level 95.0\%, $\alpha 5.0 \%$ and $e$ sample $5.0 \%$. To select the sample, the convenience and consecutiveness were adopted since the approach was given as the woman arrived at the Family Health Units and was interrupted as soon as it reached the desired number. The convenience meets the interests of research and researcher for its facility in data collection ${ }^{(4)}$. Data collection was made from the application of a specific instrument, developed by the researchers. The study included women aged between 35 and 65 years; that had undergone at least three Pap tests; registered in the study Unit and lived in urban areas. They excluded all women who, at the time of application of the instrument, showed no physical and/or mental capacity to answer it because they had motor, speech or reasoning impairment, or disorientation in time and space.

For consolidation and data analysis the Statistical Package for Social Sciences was used, and it was adopted a descriptive statistics to the proportion and as a measure of central tendency average. Thus, it sought a response which(s) factor(s) is (are) related to changes in sexual activity of women in climacteric age.

The study complied with the formal requirements contained in the national and international standards of regulatory research involving human subjects.

\section{Results}

The survey was conducted with 330 women aged from 35 to 65 years living in the urban zone of the city of Cajazeiras, Paraíba, Brazil, and had already performed at least three cytological examinations to prevent gynecological diseases 
Table 1 - Socio-demographic characterization of woman participating in the survey

\begin{tabular}{|c|c|c|}
\hline Variables & n (\%) & $\mathbf{C L}^{*}$ \\
\hline \multicolumn{3}{|l|}{ Age group (years) } \\
\hline $35-45$ & $165(50.0)$ & \\
\hline $46-55$ & $99(3.0)$ & $1.62-1.78$ \\
\hline $56-65$ & $66(20.0)$ & \\
\hline \multicolumn{3}{|l|}{ Marital status } \\
\hline With steady partner & $229(69.4)$ & $1.26-1.36$ \\
\hline Without steady partner & $101(30.6)$ & \\
\hline \multicolumn{3}{|l|}{ Education } \\
\hline Illiterate & $6(1.8)$ & \\
\hline Incomplete/complete elementary school & $153(46.4)$ & $2.55-2.71$ \\
\hline Incomplete/Complete high school & $127(38.5)$ & \\
\hline Incomplete/Complete higher education & $44(13.3)$ & \\
\hline \multicolumn{3}{|l|}{ Monthly income (wages) } \\
\hline$<1$ & $16(4.8)$ & \\
\hline $1-2$ & $274(83.1)$ & $2.03-2.12$ \\
\hline$>3$ & $40(12.1)$ & \\
\hline \multicolumn{3}{|l|}{ Race } \\
\hline White & $141(42.7)$ & \\
\hline Non-white & $189(57.3)$ & $1.52-1.63$ \\
\hline Total & $330(100.0)$ & \\
\hline
\end{tabular}

The women belonged to the minimum age group of 35 years and maximum 65 years, mean 47.2 years and fashion 38 years, whose predominant age group was between 35 and 45 years, followed by 46 and 55.

Regarding the marital status of participants, most had a steady partner. But the predominant degree of education among women was incomplete/ complete elementary school. Most have an income of 1-2 minimum wages and non-white race. It is noteworthy that $73.0 \%$ had active sexual life and $27.0 \%$ inactive.
Table 2 - Distribution of woman with active sexual life reporting complaints during sex

\begin{tabular}{lcc}
\hline Complaint & $\mathbf{n ( \% )}$ & Confidence level \\
\hline Dyspareunia & $141(58.5)$ & \\
Reduced dryness & $49(20.3)$ & \\
Itch & $3(1.3)$ & $1.68-1.65$ \\
Bleeding & $1(0.4)$ & \\
Total & $194(100.0)$ & \\
\hline
\end{tabular}

Table 2 highlights that from the 214 women with active sex life 194 presented complaints during intercourse, being dyspareunia the most frequent complaint, followed by reduced dryness. The itching and bleeding have been reported with little representation.

Table 3 - Distribution of women participating in the survey regarding the libido in the climacteric period

\begin{tabular}{lcc}
\hline Complaint & $\mathbf{n}(\%)$ & $\mathbf{C L}^{*}$ \\
\hline Decreased libido & $196(59.4)$ & \\
Without decreased libido & $134(40.6)$ & $1.36-1.47$ \\
Total & $330(100.0)$ & \\
${ }^{*}$ Confidence level & &
\end{tabular}

Table 3 shows that the majority of study participants reported decreased libido.

\section{Discussion}

The considerable difference between the number of participants in the predominant age group and other age groups was mainly the scarcity of women who met the pre-established criteria for participation in the study, particularly regarding the realization of at least three previous Pap test.

The presence of a steady partner in a woman's life generates emotional stability and, as the degree of trust and intimacy of the couple provides the reduction of the occurrence of infections, moreover, the degree of emotional intimacy with a steady partner establishes influence on the health status of the woman in middle age, as well as about their sexuality ${ }^{(5-6)}$. 
The sample consisted of women with a satisfactory level of education, an essential factor to absorb knowledge and its importance. Education is not a decisive point for the acquisition or the emergence of diseases, but a better level of education increases in the individual the ability to adopt self-care strategies that help to prevent diseases and also follow the conduct and offered guidelines ${ }^{(7)}$. It is noteworthy that in the climacteric, in addition to the symptoms, factors such as living conditions, reproductive history, type of work, eating habits, prone to infection, poor access to health services, and other cultural and socio-economic conflicts $^{(8)}$, may be associated with emotional and physical status of women.

The study group is composed of low-income women, which most often prevents the healthcare as a priority in the household budget, and often stray woman from the health service, committing their life. A good income enables a better or faster access to health services, which facilitates early diagnosis and the adoption of preventive measures ${ }^{(9)}$. Still stands out in the study, as self-reported condition, most non-white women, where education and income, social determinants of health, are less favorable, and is, according to research ${ }^{(10)}$ the group has greater difficulty in accessing health services, often related to racial discrimination.

An active sex life during climacteric can be explained by factors such as greater fellowship, the presence of new sexual partner, financial stability, long oneself dedication, absence of menstruation and consequent reduction of pregnancy chances ${ }^{(11-12)}$, a condition that offers more feminine freedom to express their sexuality and that author ${ }^{(13)}$ point out that needs to be understood considering the experience, the historical, social, economic and cultural context in which the woman is inserted. However, sexuality and sexual activity can be impaired by the occurrence of urogenital disorders such as dyspareunia and decrease dryness, more prevalent in the study as a result of hormonal decline. The most prominent sexual disorders in female sexual life are decreased libido, frequency and orgasmic response, which occurrence is related to decreased cervical mucus and vulva-vaginal atrophy, resulting from estrogen deprivation ${ }^{(1,14-15)}$.

However, these associated factors can lead to reduced libido, which places the woman in an uncomfortable position with the partner, often silent to not expose their vulnerability, fulfilling their role of women, even without desire, socio-culturally imposed. Pain, burning, discomfort and other of physical or emotional symptoms, can be minimized with the use of Hormone Replacement Therapy, given that it acts on female general aspects and restores hydration and lubrication of the vaginal mucosa and reduces hot flashes, sweating, urogenital atrophy and decreased libido $^{(16,1)}$. However, this is a controversial conduit between professionals, since it can cause various serious side effects ${ }^{(17)}$. So it should be explained and offered to the woman during the consultation, with emphasis on cost/benefit of treatment, giving the chance to opt for what they believes is best for their life as a doctor-patient shared decision.

\section{Conclusion}

Climacteric causes a series of changes in body, health, psychological and sexuality, causing in the woman complaints that interfere with their sexual life, being dyspareunia and decreased dryness the most frequent, whose solution lies in vaginitis research, treatment, dispensing lubricants, as well as Hormone Replacement Therapy according to the doctor-patient decision. Also, changes in health services practice giving more visibility to women and open spaces so that it can be seen beyond a player body that needs to be mediatized.

\section{Collaborations}

Almeida AAB and Dantas RCO contributed to the design, data collection, analysis, data interpretation, article writing and final approval of the 
version to be published. Oliveira CBD and Freitas FFQ and contributed to writing the article and the critical review of the intellectual content. Carolino MTS contributed to analysis and interpretation of data. Sousa KA contributed to final approval of the version to be published.

\section{References}

1. Ministério da Saúde (BR). Secretaria de Atenção à Saúde. Departamento de Ações Programáticas Estratégicas. Manual de atenção à mulher no Climatério/Menopausa. Brasília: Ministério da Saúde; 2008.

2. Fonseca AM, Bagnoli VR. Tratamento hormonal no climatério. Rev Bras Med. 2011; 68(10):294-99.

3. Taivora SO, Lorenzi DRS. Influência do exercício físico na qualidade de vida de mulheres na pósmenopausa. Rev Bras Geriatr Gerontol. 2011; 14(1):135-45.

4. Triola MF. Introdução à estatística. Rio de Janeiro: LTC; 2008.

5. Cavalheiro MD, Silva NMM, Tashima CM, Toledo Neto JL, Veras TCS, Melo SCCS. Ocorrência de infecções ginecológicas em gestantes. Rev Odontol. 2014; 14(4):225-37.

6. Pinto Neto AM. Climatério e sexualidade. Rev Bras Ginecol Obstet. 2013; 35(3):93-6.

7. Jesus ES, Neves RS. Diagnósticos de Enfermagem em pacientes lesados medulares. Porto Alegre: Associação Brasileira de Enfermagem; 2006.

8. Valença CN, Germano RM. Concepções de mulheres sobre menopausa e climatério. Rev Rene. 2010; 11(3):161-71.

9. Colet CF, Mayorga P, Amador TA. A utilização de medicamentos por idosos inseridos em grupos de convivência no município de Porto Alegre/ RS/Brasil. J Latino-Am Farmácia [Internet]. 2008 [citado 2015 dez 13]; 27(3):460-7. Disponível em: http://www.latamjpharm.org/trabajos/27/3/ LAJOP_27_3_3_4_09HK9Z6E90.pdf
10. Cabral PUL, Canário ACG, Spyrides MHC, Uchôa SAC, Júnior JE, Amaral RLG, et al. Influência dos sintomas climatéricos sobre a função sexual de mulheres de meia-idade. Rev Bras Ginecol Obstet. 2012; 34(7):329-34.

11. Falcke D, Zordan E. Amor, casamento e sexo: opinião de adultos jovens. Arq Bras Psicol. 2010; 62(2):143-55.

12. Ashdown B, Hackathorn J, Clark E. In and out of the bedroom: sexual satisfaction in the marital relationship. J Integrated Soc Sci. 2011; 2(1):4057.

13. Araújo IA, Queiroz ABA, Moura MAV, Penna LHG. Social representations of the sexual life of climacteric women assisted at public health services. Texto Contexto Enferm. 2013; 22(1):11422.

14. Faubion SS, Rullo JE. Sexual dysfunction in women: a practical approach. Am Fam Physician. 2015; 92(4):281-8.

15. Alves ERP, Costa AM, Bezerra SMMS, Nakano AMS, Cavalcanti AMTS, Dias MD. Climatério: a intensidade dos sintomas e o desempenho sexual. Texto Contexto Enferm. 2015; 24(1):64-71.

16. Nappi RE, Kingsberg S, Maamari R, Simon J. The CLOSER (Clarifying vaginal atrophy's impact on sex and reationships) survey: implications of vaginal discomfort in postmenopausal women and in male partners. J Sex Med. 2013; 10(9):2232-41.

17. Nakaoka VY, Silva E, Pereira AMO, Pereira IMO, Pereira MG, Espírito-Santo LF, et al. Climatério e terapia de reposição hormonal - uma revisão de literatura. Rev Uningá Rev. 2013; 16(1):5-8. 